\title{
ANALISIS PENILAIAN TINGKAT KESEHATAN BANK DENGAN METODE RISK BASED BANK RATING PADA PT BANK DANAMON INDONESIA, Tbk PERIODE 2014-2017
}

\author{
Ardiani Hayumurti *) \\ R. Gunawan Setianegara **)
}

\begin{abstract}
This research is conducted to identify the bank health rating of PT Bank Danamon Indonesia, Tbk one private bank in Indonesia in the period of 2014-2017 using the Risk Based Bank Rating (RBBR) method whether the bank is classified into one of the 5 categories: very healthy, healthy, healthy enough, not healthy enough, and unhealthy. Risk Based Bank Rating (RBBR) method is used to assess the health rating of bank based on 3 factors, i.e. Risk Profile, Earning, and Capital. This assessment with RBBR Method is done based on SEOJK Number14/SEOJK.03/2017 about the health assessment of conventional banks. The result of this research shows that: first, based on the credit risk aspect, the credit risk is low to moderate. Second, based on the liquidity risk aspect, the liquidity risk is healthy enough. Third, based on the remunerativeness seen by ROA and NIM ratio, the profitability is very adequate. Fourth, based on capital seen by KPMM or CAR ratio, the capital is very adequate.

Keywords: Banking Health assessment, RBBR, Credit Risk, Liquidity Risk, Earning, Capital

*) Mahasiswa Tugas Akhir Prodi Keuangan dan Perbankan, Jurusan Akuntansi, Politeknik Negeri Semarang

**) Dosen Jurusan Akuntansi, Politeknik Negeri Semarang
\end{abstract}

\section{PENDAHULUAN}

\section{Latar Belakang}

Perbankan adalah segala sesuatu yang menyangkut tentang bank, mencakup kelembagaan, kegiatan usaha, serta cara dan proses dalam melaksanakan kegiatan usahanya. Sedangkan, Bank adalah badan usaha yang menghimpun dana dari masyarakat dalam bentuk simpanan dan menyalurkannya kepada masyarakat dalam bentuk kredit dan atau bentuk-bentuk lainnya dalam rangka meningkatkan taraf hidup rakyat banyak (Undang-Undang Nomor 10 Tahun 1998).

Krisis tahun 1997 dan 2008, memberikan gambaran bahwa kesehatan bank dan sistem ketahanan itu penting (Widyaningrum dkk, 2014). Sehingga Bank wajib melakukan penilaian Tingkat Kesehatan Bank dengan menggunakan pendekatan risiko (Risk-based Bank Rating) baik secara individu maupun secara konsolidasi sesuai peraturan yang berlaku. Kebijakan tentang penilaian tingkat kesehatan bank diatur dalam Peraturan Otoritas Jasa KeuanganNomor 4/POJK.03/2016. Metode RBBR terdiri dari beberapa faktor yaitu Risk Profile, Good Corporate Governance (GCG), Earning, dan Capital.

Berdasarkan SE OJK No. 14/SEOJK.03/2017, untuk menganalisis tingkat kesehatan bank dengan menggunakan metode Risk Based Bank Rating (RBBR), ada 4 faktor yang dinilai, 
yaitu Faktor Profil Risiko, Good Corporate Governance (GCG), Rentabilitas dan Permodalan. Dalam Penelitian ini, yang dianalis hanya 3 faktor yang dinilai,yaitu Faktor Risiko (Risiko Kredit dan Risiko Likuiditas hal tersebut dikarenakan pada risiko kredit dan likuiditas peneliti dapat memperoleh data kuantitatif yang tidak dapat diperoleh pada faktor risiko operasional, risiko hukum, risiko stratejik, risiko kepatuhan dan risiko reputasi), Rentabilitas, dan Permodalan.

Kenaikan dan penurunan rasio kinerja keuangan Bank Danamon selama tahun 20142017 menunjukkan bahwa permasalahan dalam penelitian ini adalah kinerja Bank Danamon dapat dikatakan belum stabil sehingga Bank Danamon harus terus meningkatkan kualitas kerjanya untuk dapat menjaga resiko yang mungkin timbul akibat penurunan kinerja keuangan.

Berdasarkan fenomena bisnis tersebut penulis tertarik untuk menganalisis kinerja keuangan pada PT Bank Danamon Indonesia Tbk dan mengambil judul : "ANALISIS PENILAIAN TINGKAT KESEHATAN BANK DENGAN METODE RISK BASED BANK RATING PADA PT BANK DANAMON INDONESIA, Tbk. PERIODE 2014-2017”

\section{KAJIAN TEORI}

\section{Penilaian Kesehatan Bank}

Kesehatan suatu bank dapat diartikan sebagai kemampuan suatu bank untuk melakukan kegiatan operasional perbankan secara normal dan mampu memenuhi semua kewajiban dengan baik dengan cara-cara yang sesuai dengan peraturan perbankan yang berlaku (Budisantoso, 2013:73).

Berdasarkan Surat Edaran Otoritas Jasa Keuangan Nomor 14/SEOJK.03/2017, Bank wajib melakukan penilaian Tingkat Kesehatan Bank secara individu dengan menggunakan pendekatan risiko (Risk-based Bank Rating) dengan cakupan penilaian terhadap empat faktor yaitu Risk Profile (profil risiko), Good Corporate Governance (GCG), Earning (Rentabilitas) dan Capital (Pemodalan).

\section{Profil Risiko}

Berdasarkan POJK No. 4/POJK.03/2016 bank melakukan penilaian terhadap risiko inheren dan kualitas penerapan manajemen risiko dalam kegiatan operasional terhadap delapan risiko, yakni risiko kredit, risiko pasar, risiko likuiditas, risiko operasional, risiko hukum, risiko stratejik, risiko kepatuhan, dan risiko reputasi. Dalam penelitian ini yang dihitung adalah Risiko Kredit menggunakan rasio Non Performing Loan (NPL) dan rasio Loan to Deposit Ratio (LDR) untuk mengukur Risiko Likuiditas. NPL dihitung dengan rumus:

$$
\text { NPL }=\frac{\text { Jumlah Kredit Bermasalah }}{\text { Jumlah Kredit }} \times 100 \%
$$


Tabel 1

Peringkat Kesehatan Bank berdasarkan NPL

\begin{tabular}{|l|l|l|}
\hline \multicolumn{1}{|c|}{ Kriteria } & Peringkat & \multicolumn{1}{c|}{ Nilai } \\
\hline $\mathrm{NPL}<2 \%$ & 1 & Low \\
\hline $2 \%<\mathrm{NPL} \leq 5 \%$ & 2 & Low to Moderate \\
\hline $5 \%<\mathrm{NPL} \leq 8 \%$ & 3 & Moderate \\
\hline $8 \%<\mathrm{NPL} \leq 12 \%$ & 4 & Moderate to High \\
\hline $\mathrm{NPL}>12 \%$ & 5 & High \\
\hline
\end{tabular}

Sumber : Kodifikasi Penilaian Kesehatan Bank berdasarkan SE BI No.13/24/DPNP/2011

Risiko Likuiditas dapat dihitung menggunakan sebagai berikut :

$$
\mathrm{LDR}=\frac{\text { Total Kredit }}{\text { Dana Pihak Ketiga }} \times 100 \%
$$

Tabel 2

Peringkat Kesehatan Bank berdasarkan NPL

\begin{tabular}{|l|l|l|}
\hline \multicolumn{1}{|c|}{ Kriteria } & Peringkat & \multicolumn{1}{c|}{ Nilai } \\
\hline $50<\mathrm{LDR} \leq 75 \%$ & 1 & Sangat sehat \\
\hline $75 \%<\mathrm{LDR} \leq 85 \%$ & 2 & Sehat \\
\hline $85 \%<\mathrm{LDR} \leq 100 \%$ & 3 & Cukup sehat \\
\hline $100 \%<\mathrm{LDR} \leq 120 \%$ & 4 & Kurang sehat \\
\hline LDR $>120 \%$ & 5 & Tidak sehat \\
\hline
\end{tabular}

Sumber : Kodifikasi Penilaian Kesehatan Bank berdasarkan SE BI No.6/23/DPNP/2004

\section{Penilaian Faktor Rentabilitas ( Earning )}

Penilaian Rentabilitas merupakan penilaian terhadap kemampuan bank dalam memperoleh laba. Rasio yang digunakan untuk mengukur aspek rentabilitas menggunakan rasio Return on Asset (ROA) dan Net Interest Margin (NIM). ROA dihitung dengan rumus:

$$
\text { ROA }=\frac{\text { Laba Sebelum Pajak }}{\text { Rata-rata } \text { Total Aset }} \times 100 \%
$$

Tabel 3

Peringkat Kesehatan Bank berdasarkan ROA

\begin{tabular}{|l|l|l|}
\hline \multicolumn{1}{|c|}{ Kriteria } & Peringkat & \multicolumn{1}{c|}{ Nilai } \\
\hline ROA $>1,5 \%$ & 1 & Sangat memadai \\
\hline $1,25 \%<\mathrm{ROA} \leq 1,5 \%$ & 2 & Memadai \\
\hline $0,5 \%<\mathrm{ROA} \leq 1,25 \%$ & 3 & Cukup memadai \\
\hline $0 \%<\mathrm{ROA} \leq 0,5 \%$ & 4 & Kurang memadai \\
\hline ROA $\leq 0 \%$ & 5 & Tidak memadai \\
\hline
\end{tabular}

Sumber : Kodifikasi Penilaian Kesehatan Bank berdasarkan SE BI No.13/24/DPNP/2011

NIM dihitung dengan rumus:

$$
\mathrm{NIM}=\frac{\text { Pendapatan Bunga Bersih }}{\text { Rata-rata Total Aset produktif }} \times 100 \%
$$


Tabel 4

Peringkat Kesehatan Bank berdasarkan NIM

\begin{tabular}{|l|l|l|}
\hline \multicolumn{1}{|c|}{ Kriteria } & Peringkat & \multicolumn{1}{c|}{ Nilai } \\
\hline NIM $>3 \%$ & 1 & Sangat memadai \\
\hline $2 \%<$ NIM $\leq 3 \%$ & 2 & Memadai \\
\hline $1,5 \%<$ NIM $\leq 2 \%$ & 3 & Cukup memadai \\
\hline $1 \%<$ NIM $\leq 1,5 \%$ & 4 & Kurang memadai \\
\hline NIM $\leq 1 \%$ & 5 & Tidak memadai \\
\hline
\end{tabular}

Sumber : Kodifikasi Penilaian Kesehatan Bank berdasarkan SE BI No.13/24/DPNP/2011

\section{Penilaian Faktor Permodalan ( Capital )}

Permodalan merupakan penilaian terhadap kecukupan modal bank yang digunakan untuk melindungi risiko yang terjadi saat ini dan mengantisipasi risiko yang terjadi di masa yang akan datang. Rasio yang dapat digunakan untuk mengukur kecukupan modal yang dimiliki bank adalah Capital Adequency Ratio (CAR) atau KPMM (Kewajiban Penyediaan Modal Minimum). Semakin tinggi rasio CAR atau KPMM mencerminkan bank tersebut semakin sehat permodalannya. KPMM dihitung dengan rumus:

$$
\mathrm{KPMM}=\frac{\text { Modal }}{\text { ATMR }} \times 100 \%
$$

Tabel 5

Peringkat Kesehatan Bank berdasarkan KPMM

\begin{tabular}{|l|l|l|}
\hline \multicolumn{1}{|c|}{ Kriteria } & Peringkat & \multicolumn{1}{c|}{ Nilai } \\
\hline $\mathrm{KPMM} \geq 12 \%$ & 1 & Sangat memadai \\
\hline $9 \% \leq \mathrm{KPMM}<12 \%$ & 2 & Memadai \\
\hline $8 \% \leq \mathrm{KPMM}<9 \%$ & 3 & Cukup memadai \\
\hline $6 \%<\mathrm{KPMM}<8 \%$ & 4 & Kurang memadai \\
\hline $\mathrm{KPMM} \leq 6 \%$ & 5 & Tidak memadai \\
\hline
\end{tabular}

Sumber : Kodifikasi Penilaian Kesehatan Bank berdasarkan SE BI No.13/24/DPNP/2011

\section{METODE}

\section{Pengertian Metodologi}

Menurut Narbuko dan Achmadi (2013:1) Metode Penelitian berasal dari kata "Metode" yang artinya cara yang tepat untuk melakukan sesuatu dan "Logos" yang artinya ilmu dan pengetahuan. Jadi metodologi artinya cara melakukan sesuatu dengan menggunakan pikiran secara seksama untuk mencapai suatu tujuan. Sedangkan "Penelitian" adalah suatu kegiatan mencari, mencatat, merumuskan dan menganalisis sampai menyusun laporannya. Jadi Metodologi Penelitian adalah ilmu mengenai jalan yang dilewati untuk mencapai pemahaman.

\section{Populasi dan Sampel Data Penelitian}

Menurut Margono (2010), Populasi adalah seluruh data yang menjadi perhatian kita dalam suatu ruang lingkup dan waktu yang kita tentukan. Populasi dalam penelitian ini adalah 
Risk Profile yaitu Risiko Kredit, Risiko Pasar, Risiko Likuiditas, Risiko Operasional, Risiko Hukum, Risiko Stratejik, Risiko Kepatuhan dan Risiko Reputasi, Faktor Rentabilitas, dan Faktor Permodalan.

Sedangkan Sampel adalah sebagai bagian dari populasi, sebagai contoh (monster) yang diambil dengan menggunakan cara-cara tertentu. Kriteria penentuan sampel yang akan diambil dalam penelitian ini adalah dapat diperoleh data kuantitatif dari laporan keuangan publikasi Bank. Berdasarkan kriteria tersebut sampel yang digunakan hanya 3 faktor, yaitu Faktor Risiko (Risiko Kredit dan Risiko Likuditas), Rentabilitas, dan Permodalan.

\section{HASIL DAN PEMBAHASAN}

\section{Profil Risiko}

\section{a. Risiko Kredit}

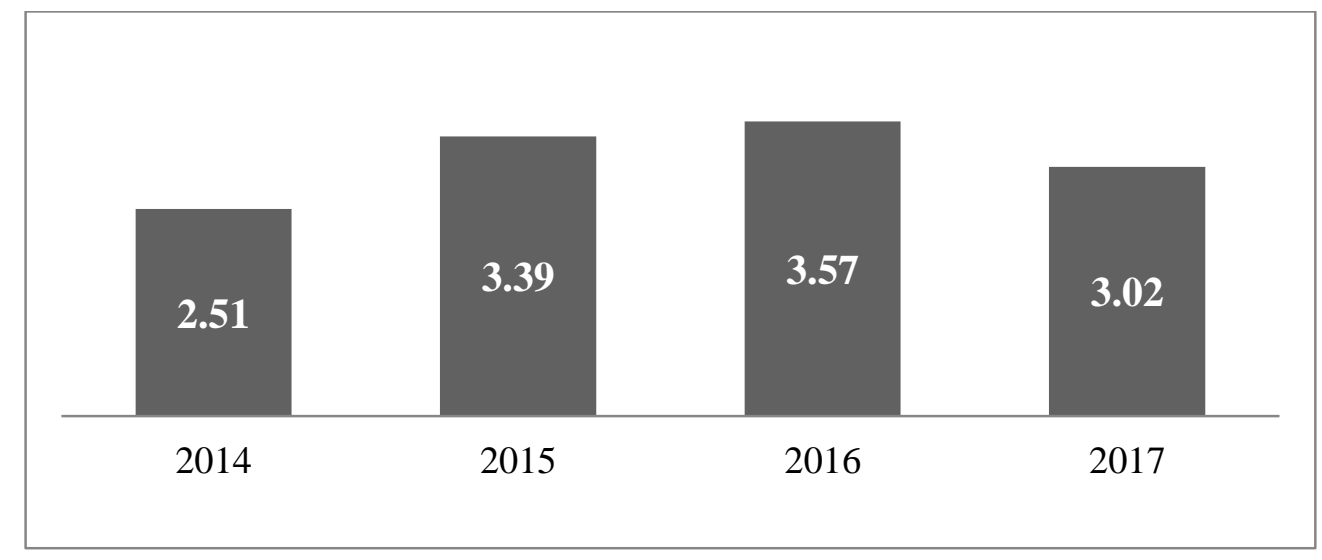

\section{Gambar 1}

NPL Bank Danamon Indonesia, Tbk. Periode 2014-2017

Sumber : Data yang diolah 2018

Meskipun NPL PT Bank Danamon Indonesia, Tbk mengalami fluktuasi tetapi profil risiko kredit masih berada pada peringkat 2 (dua) artinya dengan mempertimbangkan aktivitas bisnis yang dilakukan Bank, kemungkinan kerugian yang dihadapi Bank akibat risiko kredit tergolong rendah untuk periode 2014-2017. 


\section{b. Risiko Likuiditas}

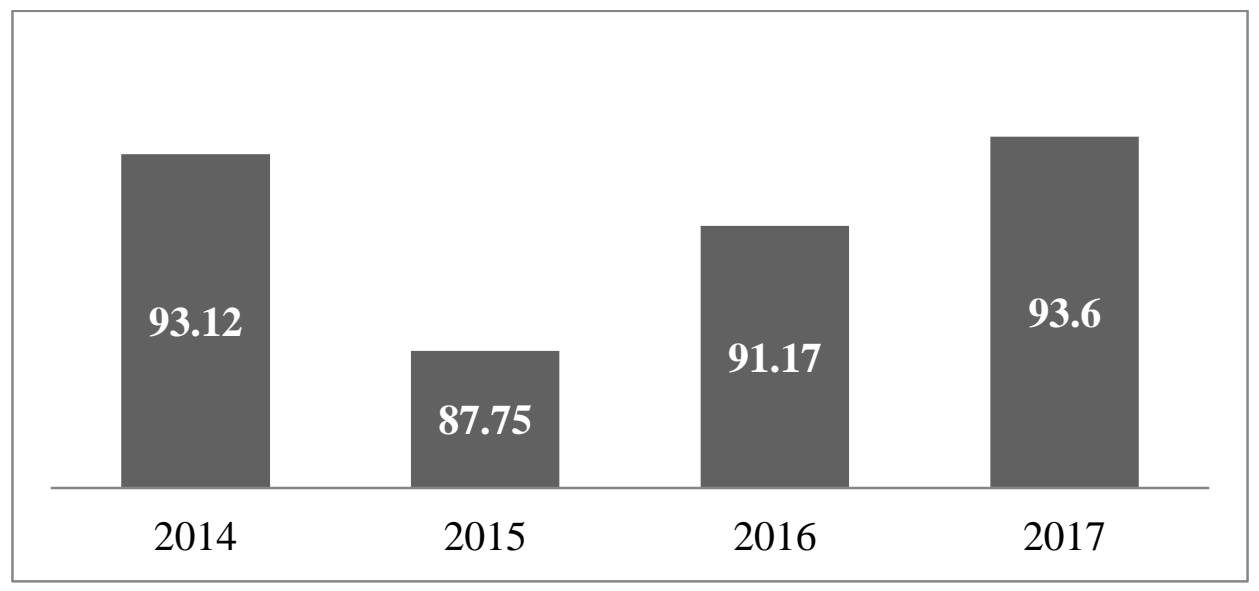

\section{Gambar 2}

LDR Bank Danamon Indonesia, Tbk. Periode 2014-2017

Sumber : Data yang diolah 2018

Dengan adanya peningkatan risiko likuiditas PT Bank Danamon Indonesia, Tbk tidak menandakan semakin baik pengelolaan risiko likuiditas Bank dan menunjukkan bahwa Bank Danamon dalam membayar kembali penarikan yang dilakukan pihak ketiga dengan mengandalkan kredit belum dilakukan dengan baik meskipun tidak tergolong buruk.

\section{Rentabilitas}

a. Return On Asset (ROA)

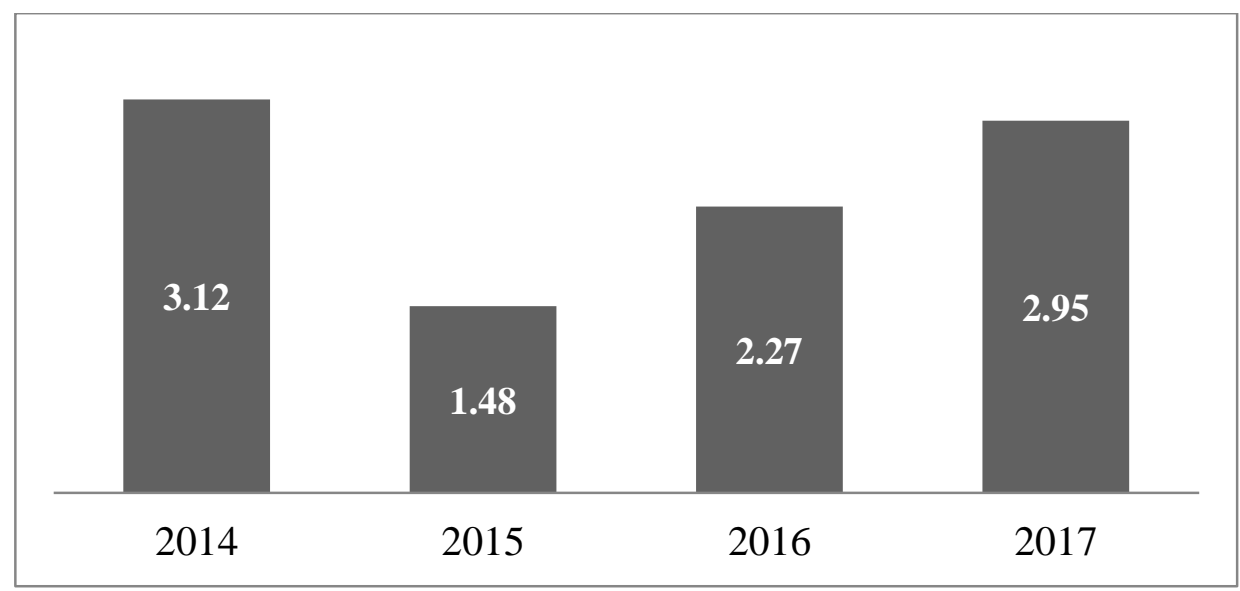

Gambar 3

ROA Bank Danamon Indonesia, Tbk. Periode 2014-2017

Sumber : Data yang diolah 2018

Hal ini menunjukkan bahwa kemampuan PT Bank Danamon Indonesia, Tbk untuk menghasilkan laba melalui total aktiva cenderung stabil. 


\section{b. Net Interest Margin (NIM)}

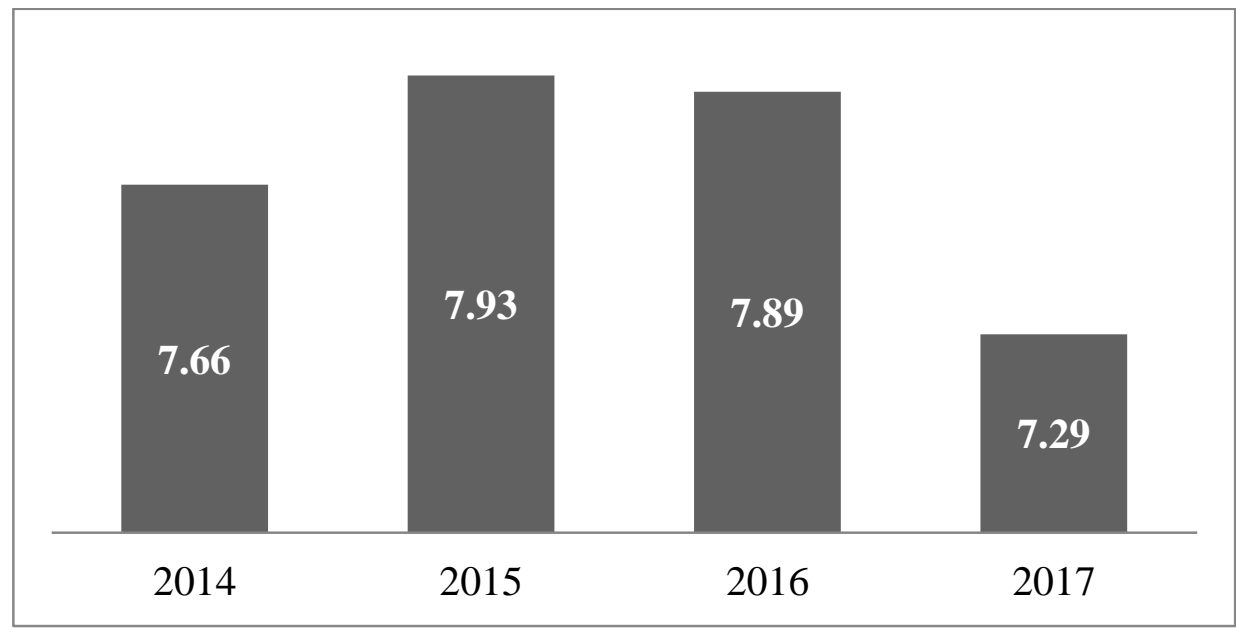

\section{Gambar 4}

NIM Bank Danamon Indonesia, Tbk. Periode 2014-2017

Sumber : Data yang diolah 2018

Dengan ini bisa dilihat kemampuan manajemen PT Bank Danamon Indonesia, Tbk dalam mengelola aktiva produktifnya untuk menghasilkan pendapatan bunga bersih sangat baik meskipun masih fluktuatif. Semakin besar NIM yang diperoleh Bank, maka semakin besar pula pendapatan bunga atas aset produktif yang dikelola Bank sehingga kemungkinan Bank dalam kondisi tidak sehat semakin kecil.

\section{Permodalan}

\section{a. Capital Adequacy Ratio (CAR)}

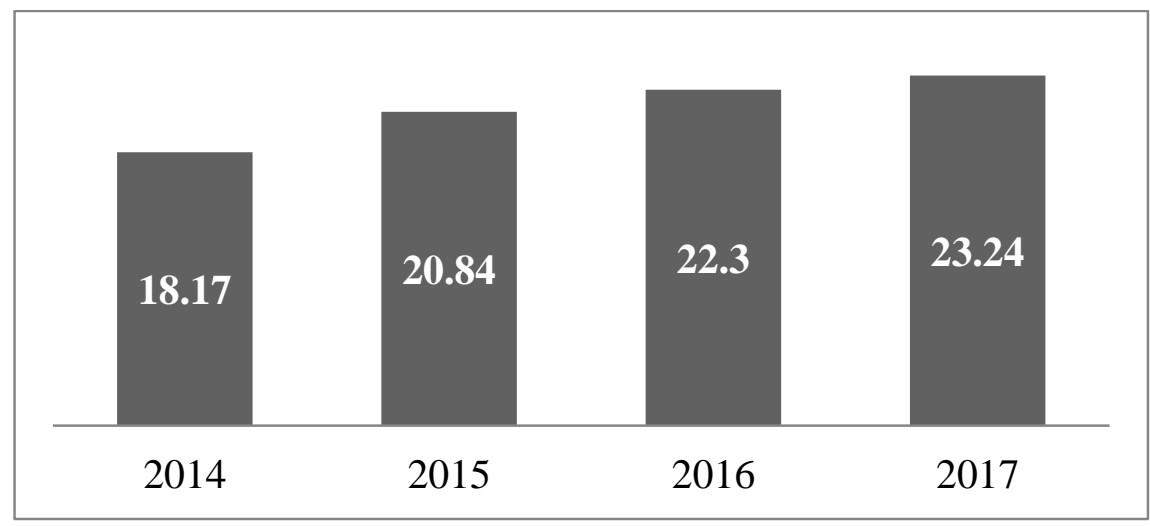

Gambar 5

CAR Bank Danamon Indonesia, Tbk. Periode 2014-2017

Sumber : Data yang diolah 2018

Selama 4 (empat) periode PT Bank Danamon Indonesia, Tbk mengalami fluktuasi namun secara konsisten tetap pada predikat sangat memadai atau peringkat 1 (satu). 


\section{KESIMPULAN DAN SARAN}

\section{Kesimpulan}

Berdasarkan hasil penilaian Risiko Kredit, Risiko Likuiditas, Faktor Rentabilitas, dan Faktor Permodalan pada PT Bank Danamon Indonesia, Tbk periode 2014-2017 yang dapat diambil kesimpulan sebagai berikut :

1. Hasil penilaian Risiko Kredit menunjukkan bahwa selama 4 (empat) periode PT Bank Danamon Indonesia, Tbk mendapat "peringkat 2 (dua)" dengan predikat "Low to Moderate" yang menunjukkan bahwa jika dinilai dari aktivitas bisnis Bank, kemungkinan kerugian yang disebabkan oleh Risiko Kredit tergolong "Rendah". Kemudian hasil penilaian Risiko Likuiditas menunjukkan bahwa selama 4 (empat) periode PT Bank Danamon Indonesia, Tbk mendapat "peringkat 3 (tiga)" atau dalam predikat "Cukup Sehat" yang menunjukkan jika dinilai dari aktivitas bisnis yang dilakukan oleh Bank, kemungkinan terjadi kerugian akibat Risiko Likuiditas tergolong “Cukup Tinggi”.

2. Hasil penilaian Faktor Rentabilitas yang diukur dengan menggunakan Rasio ROA (Return On Asset) pada periode 2014, 2016, dan 2017 PT Bank Danamon Indonesia, Tbk mendapatkan "peringkat 1 (satu)" atau predikat "Sangat Memadai" dan pada periode 2015 PT Bank Danamon Indonesia, Tbk mendapatkan “peringkat 2 (dua)” atau predikat "Memadai" yang artinya laba memenuhi target dan mendukung pertumbuhan permodalan Bank. Kemudian hasil penilaian Faktor Rentabilitas yang diukur dengan menggunakan Rasio NIM (Net Interest Margin) pada periode 2014, 2015, 2016, dan 2017 PT Bank Danamon Indonesia, Tbk mendapatkan “peringkat 1 (satu)” atau predikat "Sangat Memadai".

3. Hasil penilaian Faktor Permodalan yang diukur dengan menggunakan Rasio KPMM (Kewajiban Penyediaan Modal Minimum) atau CAR (Capital Adequacy Ratio) pada PT Bank Danamon Indonesia, Tbk menunjukkan hasil yang konsisten dengan mendapat “peringkat 1 (satu)" atau predikat "Sangat Memadai" yang artinya Bank memiliki kecukupan dalam permodalan dan memadai relatif terhadap profil risikonya, yang disertai dengan pengelolaan permodalan yang sangat kuat.

\section{Saran}

Berdasarkan penjelasan hasil analisis dan kesimpulan diatas, maka saran yang dapat dikemukakan dalam penelitian ini adalah sebagai berikut:

1. Memperluas objek penelitian dan tidak terpaku pada satu bank agar dapat melihat perbandingan mengenai kondisi kesehatan bank dengan bank yang lain (Chozin, 2016). 
2. Menggunakan periode yang lebih lama sehingga bisa melihat perkembangan kesehatan bank tersebut (Chozin, 2016).

3. Bagi peneliti selanjutnya, disarankan untuk memperluas cakupan penelitian tentang penilaian kesehatan bank dengan menggunakan indikator rasio keuangan lainnya pada pengukuran tingkat kesehatan bank dengan metode terbaru sesuai dengan Surat Edaran dari Otoritas Jasa Keuangan (Chozin, 2016).

\section{DAFTAR PUSTAKA}

Artyka, Nur. 2015. Penilaian Kesehatan Bank Dengan Metode RGEC Pada PT Bank Rakyat Indonesia (Persero) Tbk Periode 2011-2013. Skripsi. Universitas Negeri Yogyakarta

Budisantoso, Totok dan Nuritomo. 2014. Bank dan Lembaga Keuangan Lain. Jakarta: Salemba Empat.

Chozin, Muchamad Nur. 2016. Analisis Penilaian Tingkat Kesehatan Bank Dengan Menggunakan Metode Risk Based Bank Rating (RBBR) Periode 2012-2015 (Studi Pada PT Bank Rakyat Indonesia (Persero), Tbk). Tugas Akhir. Semarang: Politeknik Negeri Semarang

Dendawijaya, Lukman. 2003. Manajemen Perbankan. Jakarta: Ghalia Indonesia

Fadhila, Alizatul., Muhammad Saifi dan Zahroh Z.A. 2015. Analisis Tingkat Kesehatan Bank Dengan Menggunakan Metode Risk Based Bank Rating (RBBR) (Studi pada Bank Milik Pemerintah Pusat yang Terdaftar di Bursa Efek Indonesia Tahun 2011-2013). Jurnal Administrasi Bisnis. Malang: Universitas Brawijaya

Hariasih, Misti. 2015. Analisis Kinerja Bank Dengan Penerapan Metode Risk Based Bank Rating (RBBR) Studi Pada Bank Umum Milik Negara Yang Listing Di BEI. Laporan Penelitian. Program Studi Manajemen, Fakultas Ekonomi \& Bisnis Universitas Muhammadiyah Sidoarjo.

Lasta, Heidy Arrvida., Zainul Arifin dan Nila Firdausi Nuzul. 2015. Analisis Tingkat Kesehatan Bank dengan Menggunakan Pendekatan RGEC ( Risk Profile, Good Corporate Governance, Earnings, Capital) (Studi pada PT Bank Rakyat Indonesia,Tbk Periode 2011-2013). Jurnal Administrasi Bisnis. Fakultas Ilmu administrasi. Malang: Universitas Brawijaya

Margono. 2010. Metodologi Penelitian Pendidikan. Jakarta : Rineka Cipta

Masnawati, Meina Wulansari Yusniar, Abdul Hadi. 2013. Penilaian Tingkat Kesehatan Bank Dengan Menggunakan Pendekatan Risiko (Risk-Based Bank Rating) Studi pada Laporan Keuangan PT. Bank Pembangunan Daerah Kalimantan Selatan Tahun 2012. Jurnal Wawasan Manajemen. Banjarmasin: Universitas Lambung Mangkurat 
Narbuko, Cholid dan Abu Achmadi. 2013. Metode Penelitian. Jakarta : PT Bumi Askara

Pandia, Frianto. 2012. Manajemen Dana Dan Kesehatan Bank. Jakarta : Rineka Cipta

Permata, Diah Nurriza Indah., Fariyana Kusumawati dan Rindah F. Suryawati. 2012. Pengaruh Penerapan Good Corporate Governance terhadap kinerja Keuangan Perusahaan. Jurnal Investasi. Universitas Trunojoyo Madura

Pramana, Komang Mahendra. Analisis Tingkat Kesehatan Bank (Pendekatan RGEC) Pada PT. Bank Danamon Indonesia Tbk. Skripsi. Denpasar: Universitas Udayana

Puspita, Ardian Eka. 2014. Analisis Tingkat Kesehatan Bank dengan Metode RGEC pada Bank BUMN yang Terdaftar di Bursa Efek Indonesia Tahun 2011-2012. Skripsi. Fakultas Ekonomi dan Bisnis Program Studi Akuntansi Universitas Muhammadiyah Surakarta Suhartono, Dea Amelia., Zahroh ZA dan Devi Farah Azizah. 2017. Analisis Tingkat Kesehatan Bank Dengan Menggunakan Metode Risk Based Bank Rating (Studi pada Bank Milik Pemerintah Pusat yang Terdaftar di Bursa Efek Indonesia Tahun 2012-2015). Jurnal Administrasi Bisnis. Malang: Universitas Brawijaya

Sulistyowati, Catur., Sri Mangesti Rahayu dan Zahroh Z. A. 2016. Penentuan Tingkat Kesehatan Bank Dengan Metode Risk Based Bank Rating (Studi Kasus Pada BUSN Devisa yang terdaftar di BEI Periode 2012-2014). Jurnal Administrasi Bisnis. Malang: Universitas Brawijaya

Susanti, Sandhy Dharmapermata. 2015. Analisis Tingkat Kesehatan Bank Dengan Menggunakan Metode Risk Based Bank Rating (RBBR). Skripsi. Universitas Negeri Yogyakarta

Widiyanto, Andi. 2015. Analisis Tingkat Kesehatan Bank Dengan Menggunakan Metode Risk Based Bank Rating (RBBR). Studi pada Bank yang terdaftar di Bursa Efek Indonesia dalam IHSG Sub Sektor Perbankan Tahun 2012-2014. Skripsi. Universitas Dian Nuswantoro

Widyaningrum, Hening Asih., Suhandak dan Topowijoyo. 2014. Analisis Tingkat Kesehatan Bank Dengan Menggunakan Metode Risk-Based Bank Rating (RBBR). Jurnal Administrasi Bisnis. Malang: Universitas Brawijaya

Wiyono, Gendro. 2011. 3 in One Merancang Penelitian Bisnis dengan alat analisis SPSS 17.0 \& SmartPLS 2.0. Yogyakarta : UUP STIM YPKN

Yessi, Ni Putu Noviantini Permata., Sri Mangesti Rahayu dan Maria Goretti Wi Endang NP. 2015. Analisis Tingkat Kesehatan Bank dengan Menggunakan Pendekatan RGEC Studi Pada Bank Sinar Harapan Bali Periode 2010-2012. Skripsi. Universitas Negeri Yogyakarta 